Joanna Sylwia Kierzkowska*

\title{
PRAKTYCZNY WYMIAR DECENTRALIZACJ ORAZ SCENTRALIZOWANIA CZECŚCI ZADAŃ W SYTUACJI KRYZYSOWEJ NA PRZYKŁADZIE DZIAŁAŃ PODEJMOWANYCH PO NAWAŁNICACH W BORACH TUCHOLSKICH
}

\section{Wstęp}

Ogólna awersja do centralizacji i powszechny entuzjazm doktryny do zdecentralizowanego modelu administracji zdaje się utwierdzać w przekonaniu co do słuszności spojrzenia na zagadnienie przez pryzmat najświeższych, w zasadzie nadal trwających wydarzeń mających bezpośredni wpływ na życie codzienne mieszkańców. Określenie obszaru badawczego oraz podjęcie próby analizy problemu wykonywania zadań w sytuacji kryzysowej po nawałnicach nie jest przypadkowe, jest ono bowiem obserwowane osobiście. Zbadanie praktycznego aspektu decentralizacji i centralizacji zadań administracji publicznej w sytuacji kryzysowej na przykładzie działań podejmowanych po nawałnicach w Borach Tucholskich jest możliwe tylko poprzez sekwencyjność badań. Przyjętemu podziałowi odpowiadać będą cztery fragmenty badawcze, w których poszukiwane mają być odpowiedzi na następujące pytania:

Joanna Sylwia Kierzkowska - doktor nauk prawnych, Gdańska Szkoła Wyższa, Bydgoska Szkoła Wyższa. 
1) jakie są ogólne założenia doktrynalne w zakresie pojęć centralizacji i decentralizacji?;

2) jakiego rodzaju zagrożeniem jest „nawałnica” i czy jest to pojęcie prawne?;

3) jak wygląda wykonywanie zadań w sytuacji kryzysowej w normach prawnych $z$ uwzględnieniem aspektu centralizacji i decentralizacji?;

4) jak wyglądało podejmowanie konkretnych działań różnych podmiotów po nawałnicy w Borach Tucholskich?

Ostatnie z postawionych pytań ma wymiar praktyczny, który na tle założeń doktrynalnych i prawnych pozwoli na sformułowanie odpowiednich wniosków końcowych.

\section{Decentralizacja i centralizacja w założeniach ogólnych}

Dwoma sposobami zorganizowania ustroju administracji publicznej jest decentralizacja oraz centralizacja. Współcześnie większość państw posiada administrację lub jej elementy charakterystyczne dla obu tych typów organizacyjnych.

Scentralizowanie administracji, konkretniej jej organów, polega na hierarchicznym podporządkowaniu. Najczęściej chodzi o podporządkowanie osobowe i służbowe. Pierwsze z nich polega na zależności osób, które pełnią funkcję w organach podległych organowi nadrzędnemu. Podporządkowanie służbowe pozwala na ingerencję organu zwierzchniego $\mathrm{w}$ funkcjonowanie i działanie organu podporządkowanego ${ }^{1}$. Decentralizacja $z$ kolei polega na przekazaniu pewnych zadań, które leżą „w kompetencji centrum na inne podmioty”2. Podmioty te otrzymują określone zadania od państwa i wykonują je w sposób samodzielny. Cechą charakterystyczną jest ich nieza-

1 Więcej na temat decentralizacji zob. Z. Bukowski, T. Jędrzejewski, P. Rączka, Ustrój samorządu terytorialnego, Toruń 2003, s. 20-22.

2 Z. Bukowski, T. Jędrzejewski, P. Rączka, Ustrój..., s. 23. 
leżność i gwarancja zapewnienia przez państwo samodzielności finansowej. „Decentralizacja nie oznacza jednak całkowitego uniezależnienia podmiotów zdecentralizowanych od państwa"3. Podmioty zdecentralizowane pozostają pod pewnym nadzorem państwa. Zadania publiczne wykonywane są przez niezależne i samodzielne organy, które nie są podporządkowane organom naczelnym. Wykonują one zadania we własnym imieniu i na własną odpowiedzialność. Istotne jest, aby wykonywać te zadania w sposób jak najbardziej skuteczny ${ }^{4}$. Organizacja administracji zdecentralizowanej nie jest zorganizowana na zasadzie hierarchicznego podporządkowania jednych organów innym. Obecnie w Polsce samorząd terytorialny stanowi przykład zorganizowania zdecentralizowanego. Samorząd działa na rzecz społeczności lokalnej i regionalnej, którą reprezentuje i przed która odpowiada (w związku z prowadzonymi przez siebie działaniami). Należy pamiętać, iż zdecentralizowanie działań nie oznacza wykonywania zadań bezprawnych. Muszą one być działaniami legalnymi, dopuszczonymi do realizacji w demokratycznym państwie prawa $^{5}$, ale ich specyfika jest na tyle charakterystyczna dla danego terenu (danej sytuacji), iż przeprowadzanie ich z pozycji centralnej powoduje brak możliwości realizacyjnych (paraliż realizacyjny). Założeniem decentralizacji jest autonomia decyzyjna. Wykonywanie zadań następuje u źródła problemu. Przepływ informacji jest szybki. Można mówić nawet o pewnej mobilności decyzyjnej. W przypadku jednostek samorządu terytorialnego samodzielność organizacyjną dopuszcza art. 169 ust. 4 Konstytucji RP. W przepisie unormowano bowiem, iż ustrój wewnętrzny określają w granicach ustaw ich organy stanowiące. Jednostki te podlegają jednak nadzorowi między innymi wojewody ${ }^{6}$. Z kolei art. 15 ust. 1 Konstytucji RP ustala fakt decentralizacji administracji publicznej, normuje bowiem koniecz-

3 Z. Bukowski, T. Jędrzejewski, P. Rączka, Ustrój..., s. 23.

${ }^{4} \mathrm{Na}$ temat konkretnych przykładów dotyczących skuteczności w przepisach prawa, w tym w odniesieniu do wykonywania zadań publicznych, zob. M. Maciejewski, Skuteczność jako wartość prawa administracyjnego i administracji publicznej [w:] Aksjologia prawa administracyjnego, red. J. Zimmermann, Warszawa 2017, s. 165-169.

5 Zob. Prawo administracyjne, red. M. Wierzbowski, Warszawa 1999, s. 49-50.

${ }^{6}$ O pozostałych organach nadzoru zob. J. Sługocki, Prawo administracyjne, Kraków 2003, s. 437. 
ność zapewnienia decentralizacji władzy publicznej w ustroju terytorialnym Rzeczypospolitej Polskiej.

Należy podkreślić, iż odmienne są pojęcia koncentracji oraz dekoncentracji. Pierwsze $z$ ich oznacza skupienie wykonywania zadań publicznych przez jeden organ, na przykład wyłącznie przez ministra właściwego do spraw bezpieczeństwa publicznego. Dekoncentracja oznacza zaś podział zadań publicznych (jako całości lub grupy zadań przedmiotowych) między różne organy (podmioty), dla przykładu przez ministra właściwego do spraw administracji publicznej oraz ministra właściwego do spraw bezpieczeństwa. Wskazany przykład stanowi rodzaj dekoncentracji poziomej, niekiedy nazywanej resortową. Oprócz niej wyróżnia się dekoncentrację pionową. Dekoncentracja w pionie w zakresie realizacji zadań jest potrzebna, aby umożliwić wykonywanie zadań w sposób dostosowany do warunków regionalnych czy lokalnych.

\section{3. „Nawałnica” zagrożeniem o charakterze naturalnym oraz jako pojęcie prawne}

Pojęcie nawałnicy z punktu widzenia zagrożeń dla bezpieczeństwa nie jest używane w typowej terminologii zagrożeń ekologicznych czy środowiskowych. Najczęściej mowa jest o silnych wiatrach, wichurze czy burzy. M. Graniczny i W. Mizerski do katastrof przyrodniczych zaliczają między innymi: huragany, tornada, cyklony i tsunami ${ }^{8}$.

Jeśli chodzi o najbardziej popularny podział zagrożeń bezpieczeństwa ekologicznego, mowa jest o dwóch grupach zagrożeń. Pierwsza ma charakter zagrożeń naturalnych, a druga - zagrożeń antropogenicznych, czyli takich, w których człowiek w sposób bezpośredni lub pośredni przyczynił się (wskutek negatywnych oddziaływań na śro-

7 Decentralizacja samorządu terytorialnego w ustroju terytorialnym stanowi przedmiot analizy [w:] K. Bednarzewski, P. Chmielnicki, W. Kisiel, Prawo samorządu terytorialnego w Polsce, Warszawa 2006, s. 41-43.

${ }^{8}$ M. Graniczny, W. Mizerski, Katastrofy przyrodnicze, Warszawa 2007, s. 77 i n. oraz $88-98$. 
dowisko naturalne) do powstania określonego zagrożenia. Nawałnicę można zakwalifikować do obu grup. Z jednej strony jest ona bowiem zjawiskiem o charakterze naturalnym, choć z drugiej strony coraz częściej w nauce podkreśla się, iż większość współczesnych kataklizmów naturalnych ma swoje źródło w ociepleniu klimatu9 ${ }^{9}$ czyli ma podłoże antropogeniczne, do tej negatywnej zmiany w środowisku naturalnym doprowadził bowiem człowiek. Według Encyklopedii powszechnej PWN, „nawałnica” to „szkwał, duży wzrost prędkości wiatru [...] w krótkim okresie czasu (kilka minut) połączony ze zmianą kierunku wiatru i wzrostem ciśnienia atmosferycznego", któremu zazwyczaj towarzyszy „spadek temperatury oraz wzrost zachmurzenia" ${ }^{10}$. Z kolei internetowy słownik PWN nawałnicę uznał za gwałtowną burzę z silnym wiatrem, ale także za gwałtowną ulewę lub śnieżycę $\mathrm{z}$ wichurą ${ }^{11}$.

W przepisach prawnych unormowano pojęcie katastrofy naturalnej. Zgodnie z ustawą z 18.04.2002 r. o stanie klęski żywiołowej ${ }^{12}$ ustawo- $^{2}$ dawca wskazuje, że chodzi o „zdarzenie związane z działaniem sił natury”. Wymienia przykładowe „naturalne” zdarzenia w postaci: wyładowań atmosferycznych, wstrząsów sejsmicznych, silnych wiatrów, intensywnych opadów atmosferycznych, ekstremalnych temperatur, osuwisk ziemi, pożarów, suszy, powodzi, zjawisk lodowych na rzekach i morzu oraz jeziorach i zbiornikach wodnych, masowo występujących szkodników, chorób roślin lub zwierząt albo chorób zakaźnych ludzi lub też działanie innego żywiołu. Wobec powyższego można uznać, że chodzi także o zdarzenie w postaci „nawałnicy”.

Zagrożenia, które mogą naruszyć bezpieczeństwo ekologiczne w Polsce, wskazano w „Krajowym Planie Zarządzania Kryzysowego. 2012”. Tutaj do grupy zagrożeń naturalnych zaliczono huragany. W treści

${ }^{9} \mathrm{Na}$ temat wpływu działalności człowieka na zmiany klimatyczne i wywołanie tzw. efektu cieplarnianego zob. J. Boryczka, M. Stopa-Boryczka, K. Kożuchowski, Zmiany klimatu wywołane przez człowieka [w:] Katastrofy i zagrożenia we współczesnym świecie, red. W. Baturo, Warszawa 2008, s. 76-82.

${ }^{10}$ Encyklopedia Powszechna PWN, red. H. Bonecki, t. 1, Warszawa 1973.

${ }^{11}$ https://sjp.pwn.pl/sjp/nawalnica;2487665.html (dostęp: 1.11.2018 r.).

12 Dz.U. z 2017 r. poz. 1897. 
tego dokumentu planistycznego wskazano, iż zjawisko to prowadzi do uszkodzeń budynków i budowli. Szczególnie narażone, zdaniem autorów dokumentu, są dachy. Wskutek huraganu dochodzi do wielu uszkodzeń i wyrywania drzew z korzeniami. Ponadto podkreślono, że zjawisko huraganu negatywnie wpływa na komunikację i prowadzi do uszkodzeń napowietrznych linii energetycznych. Uznano także, iż huragan w skrajnych przypadkach prowadzi do zagrożenia życia ludzi. Dokument diagnozuje, że najsilniejsze huragany na terenie Polski występują na obszarze Dolnego Śląska, dorzecza Odry w Małopolsce oraz na południu Polski.

W „Krajowym Planie Zarządzania Kryzysowego. 2012” jako zagrożenie wskazano także trąby powietrzne (tornada). Są one nowym zjawiskiem w Polsce. Najczęściej są one spotykane w Ameryce Północnej. Określenie „trąba powietrzna” jest zasadniczo używane do wyróżnienia tego groźnego zjawiska meteorologicznego w europejskich szerokościach geograficznych. Natomiast nazwa „tornado” używana jest dla obszarów ich najczęstszego występowania w kilku stanach Ameryki Północnej ${ }^{13}$.

W ostatnich latach trąby powietrzne także na terenie Polski przyczyniają się do ogromnych szkód wyrządzanych ludziom, ich mieniu oraz środowisku naturalnemu. Dotąd uznawano, iż najbardziej intensywną trąbą powietrzną była ta, która nawiedziła Lublin w 1931 r. Zginęły wtedy trzy osoby, a kilkanaście zostało rannych. Z kolei w 1960 r. na przedmieściach Rzeszowa wskutek trąby powietrznej zginęły cztery osoby, a 77 było rannych. Trąby powietrzne niszczą również środowisko naturalne. W ostatnich latach zniszczone zostały olbrzymie kompleksy leśne w Puszczy Piskiej (w 2002 r. ucierpiało 12 tys. hektarów lasu) oraz w Borach Tucholskich (w 2012 r. ok. 500 hektarów lasów) ${ }^{14}$.

${ }^{13} \mathrm{~W}$ dniach 4-9.09.2017 r. ogromne tornado przeszło nad wyspami Morza Karaibskiego. Niespotykany dotąd huragan spowodował śmierć co najmniej 21 osób. Straty materialne, które spowodował żywioł w USA, na Antylach i na Karaibach, są ogromne. Szacuje się, iż z powodu kataklizmu ucierpiało 1,2 miliona osób. Następnie 10.09.2017 r. huragan uderzył w wybrzeże Florydy, pustosząc miejscowości na niespotykaną dotąd skalę.

14 Dane te powtarzają się w częściach opisowych wojewódzkich planów zarządzania kryzysowego. 
Pojęcie huraganu w polskim prawie określone jest w ustawie z 7.07.2005 r. o ubezpieczeniu upraw rolnych i zwierząt gospodarskich $^{15}$. Zgodnie $\mathrm{z}$ art. 3 ust. 2 pkt 2 wskazywanego aktu o huraganie jest mowa, kiedy „szkody powstałe w wyniku działania wiatru o prędkości nie mniejszej niż $24 \mathrm{~m} / \mathrm{s}$, którego działanie wyrządza masowe szkody”. Poza tym „pojedyncze szkody uważa się za spowodowane przez huragan, jeżeli w najbliższym sąsiedztwie stwierdzono działanie huraganu".

W wojewódzkim planie zarządzania kryzysowego dla województwa kujawsko-pomorskiego ${ }^{16}$ wskazano, iż „strefa klimatu umiarkowanego, w której leży województwo kujawsko-pomorskie, jest narażona na występowanie wichur, czasem gwałtownych, związanych z ogólną cyrkulacją atmosfery w danej strefie szerokości geograficznej, a także na powstawanie silnych wiatrów lokalnych i tworzenie się szczególnie niebezpiecznych trąb powietrznych". Dalej w dokumencie znajduje się stwierdzenie, że „wichury występują najczęściej w okresie od listopada do marca, natomiast trąby powietrzne najczęściej od czerwca do sierpnia, czasem w maju". Wydarzeniami szczególnie niebezpiecznymi stają się trąby powietrzne, czyli jak wskazano w planie, w sytuacji gdy przemieszcza się „silny wir” mający prędkość „30-40 km/godz.” Poza tym w planie wojewódzkim podkreślono, że zazwyczaj powstaniu tych wskazywanych zjawisk towarzyszą odpowiednie, sprzyjające warunki, czyli „znaczna różnica temperatury i wilgotności na granicy dwóch mas powietrza”. Opis wyglądu „wiru” wskazuje, iż chodzi o "postać ciemnego leja zwężającego się ku dołowi, dochodzącego do powierzchni ziemi”. Określanie skali wiatru jest sześciostopniowe. Według skali Fujity w sytuacji, kiedy wiatr niszczy budynki mocnej konstrukcji, wyrywa drzewa z korzeniami, przewraca i niszczy samochody i wagony kolejowe, chodzi o wiatr w skali F3. Natomiast trąba powietrzna zanotowana w Lublinie w latach 30. miała szacunkową siłę F3-F4. Jak wskazuje się w planie wojewódzkim, „katastrofalne skutki przejścia trąby powodują jednak nie tylko duże prędkości wi-

15 Dz.U. z 2017 r. poz. 2047 ze zm.

${ }_{16}$ Zob. http://www.bip.bydgoszcz.uw.gov.pl/files/dokumenty/plan_zk_kujawsko_ pomorskie_czesc_i.pdf (dostęp: 1.11.2018 r.). 
rującego powietrza, ale również ogromna siła ssąca powstająca w osi wiru, gdzie gwałtownie spada ciśnienie. Siła ta jest w stanie wyrwać drzewa z korzeniami, porwać ludzi, auta, dachy budynków i przenieść je na odległość kilkudziesięciu metrów. Czas trwania tego zjawiska w danym miejscu wynosi od kilku sekund do kilku minut”. W badanym dokumencie nie używa się pojęcia nawałnicy.

W wojewódzkim planie zarządzania kryzysowego dla województwa pomorskiego w punkcie dotyczącym „charakterystyki zagrożeń i oceny ryzyka ich wystąpienia”, w grupie „klęski żywiołowe” wskazano, obok silnego wiatru, wichury, trąby powietrznej także „nawalny deszcz” ${ }^{17}$.

Dalsze poszukiwanie terminu „nawałnica” nakazuje powrót do nauki ekologii. Tu badanie najczęściej wiedzie ku wskazaniu, iż chodzi o burzę, która cechuje się gwałtownym wzrostem prędkości wiatru i zmianą (gwałtownymi zmianami) jego kierunku z ulewnym deszczem.

W sezonie wiosennym i letnim 2017 r. zaobserwować można było w Polsce bardzo dynamiczny sezon burzowy. Punktem kulminacyjnym było tzw. bow echo. Specyficzny obraz radarowy układu konwekcyjnego z centralnej i północnej Polski, który zwiastuje silne wiatry i tornada ${ }^{18}$. Jest to rzadki fenomen, za który odpowiada mezoskalowy układ konwekcyjny (MCS), w wyniku którego powstają gwałtowne burze i tzw. burze wielokomórkowe.

\section{Wykonywanie zadań w sytuacji kryzysowej}

Zadania w sytuacjach kryzysowych w prawie polskim określone są przez odpowiednie, hierarchicznie skonstruowane normy prawne. Jednak samego pojęcia kryzysu na gruncie prawnym próżno szukać. W Konstytucji RP w art. 228 znajdują się jedynie przesłanki wpro-

17 Zob. http://www.gdansk.uw.gov.pl/attachments/article/1545/Plan\%20G\%C5\% 82\% C3\%B3wny\%20z\%20 Planu\%20Zarz\%C4\% 85 dzania\%20 Kryzysowego \% 20Wojew\%C3\%B3dztwa\%20Pomorskiego.pdf (dostęp: 14.09.2017 r.).

18 Zob. http://trojmiasto.wyborcza.pl/trojmiasto/7,35612,22233258,skutki-nie-musialbyc-tak-tragiczne-ale-nie-ma-systemu-ostrzegania.html (dostęp: 13.09.2017 r.). 
wadzenia „stanu nadzwyczajnego”. Chodzi o sytuacje „szczególnych zagrożeń”, gdzie jednym z trzech wymienianych stanów tego rodzaju jest „stan klęski żywiołowej” ${ }^{19}$. Należy przypomnieć, że po wprowadzeniu takiego stanu "mogą zostać ograniczone wolności i prawa człowieka i obywatela". Między innymi z tego powodu władze publiczne nie zdecydowały się na wprowadzenie stanu nadzwyczajnego w sytuacjach różnych klęsk, które miały miejsce w Polsce w okresie potransformacyjnym.

Zadania w sytuacji kryzysowej wykonują organy właściwe w sprawach zarządzania kryzysowego. Zadania te i zasady działania obecnie normuje ustawa z 26.04.2007 r. o zarządzaniu kryzysowym ${ }^{20}$. Samo „zarządzanie kryzysowe” w art. 2 tej ustawy określone zostało jako działalność odpowiednich organów ${ }^{21}$. Działalność ta wchodzi w skład „kierowania bezpieczeństwem narodowym”. Wszelkie działania służą „zapobieganiu sytuacjom kryzysowym” oraz prowadzą do odpowiedniego przygotowania, aby można było przejąć nad nimi kontrolę 22 . Kontrola ta jest możliwa jedynie w drodze uprzednio zaplanowanych działań. Jednak od razu należy zaznaczyć, iż planowanie to może być jedynie pewnym scenariuszem działań, rozwój sytuacji kryzysowej w przypadku działania żywiołu może bowiem okazać się nieprzewidywalny. Jednak jak wskazuje ustawa, zarządzanie to musi polegać na „przygotowaniu do przejmowania nad nimi kontroli w drodze zaplanowanych działań” oraz „reagowaniu w przypadku wystąpienia sytuacji kryzysowych”, a także „usuwaniu ich skutków oraz odtwarzaniu zasobów i infrastruktury krytycznej"23.

19 Tu odpowiednie regulacje znajdują się w ustawie z 18.04.2002 r. o stanie klęski żywiołowej.

${ }^{20}$ Dz.U. z 2018 r. poz. 1401 ze zm. - dalej jako: ustawa o zarządzaniu kryzysowym.

${ }^{21}$ Ich podstawowe wskazanie umieścił w swojej publikacji J. Gierszewski - zob. J. Gierszewski, Bezpieczeństwo wewnętrzne, Warszawa 2013, s. 188. Autor eksponuje tu rolę komendanta powiatowego PSP oraz organów wykonawczych gminy.

22 Pojęcie sytuacji kryzysowej na gruncie bezpieczeństwa państwa może być rozumiane jako zachwianie bezpieczeństwa. Zachwianie to odnosi się do egzystencjalnych potrzeb jednostek i grup społecznych, a nawet całego państwa. Rozważania doktrynalne we wskazanym aspekcie zob. A. Łuczyszyn, Bezpieczeństwo państwa a rozwój społeczno-gospodarczy. Aspekt regionalny i lokalny, Warszawa 2016, s. 16.

${ }^{23}$ Art. 2 ustawy o zarządzaniu kryzysowym. 
Pojęcie sytuacji kryzysowej określa art. 3 pkt 1 wskazanej wyżej ustawy. Oznacza ono „sytuację wpływającą negatywnie na poziom bezpieczeństwa ludzi, mienia w znacznych rozmiarach lub środowiska, wywołującą znaczne ograniczenia w działaniu właściwych organów administracji publicznej ze względu na nieadekwatność posiadanych sił i środków”.

Z kolei „infrastruktura krytyczna” obejmuje systemy oraz wchodzące w ich skład powiązane ze sobą funkcjonalnie obiekty. Chodzi o „obiekty budowlane, urządzenia, instalacje, usługi kluczowe dla bezpieczeństwa państwa i jego obywateli oraz służące zapewnieniu sprawnego funkcjonowania organów administracji publicznej, a także instytucji i przedsiębiorców”. Ustawodawca wymienia konkretne systemy, które są zaliczone do tej kategorii. Chodzi o zaopatrzenie w energię, surowce energetyczne i paliwa, łączność, sieci teleinformatyczne, finansowe, zaopatrzenie w żywność, zaopatrzenie w wodę, ochronę zdrowia, sieci transportowe i ratownicze. Ponadto, infrastrukturą krytyczną są obiekty, które mają zapewnić ciągłość działania administracji administracji publicznej, produkcji, składowania, przechowywania i stosowania substancji chemicznych i promieniotwórczych, w tym rurociągów substancji niebezpiecznych.

Zgodnie z art. 5 badanego aktu tworzony jest Krajowy Plan Zarządzania Kryzysowego oraz wojewódzkie, powiatowe i gminne plany zarządzania kryzysowego. Na potrzeby planu krajowego, zgodnie z art. 5a, tworzony jest „Raport o zagrożeniach bezpieczeństwa narodowego”. Z kolei na podstawie art. 5b Rada Ministrów przyjmuje, w drodze uchwały, Narodowy Program Ochrony Infrastruktury Krytycznej.

Badanie w dalszej części skupione jest na wykonywaniu konkretnych działań po nawałnicy, dlatego konieczne jest wskazanie prawnych możliwości ich wykonywania. Niewątpliwie potrzebne jest spojrzenie na problem z punktu widzenia samej konstrukcji prawnej układu podmiotów zarządzania kryzysowego. Chodzi tu bowiem o schemat całego systemu, który ma postać czteropoziomową. Pierwszym z nich jest poziom centralny, kolejne trzy znajdują się na poziomie regionalnym, powiatowym i gminnym. Przypominając wskazywany już art. 15 
Konstytucji RP, odnoszący się do konieczności zapewnienia decentralizacji, to w kontekście wykonywania zadań w sytuacji kryzysowej właściwsze będzie mówienie o ich faktycznym wykonywaniu w odwrotnym układzie wskazanych wyżej poziomów, czyli od lokalnego ku poziomowi centralnemu. Wydawać się to może konieczne także przez pryzmat zadań wykonywanych przez jednostki samorządu terytorialnego, gdzie ustawodawca wiodącą rolę zagwarantował gminie. Jednak biorąc pod uwagę zespolenie służb, inspekcji i straży oraz konieczność ich współdziałania i koordynacji na rzecz wykonywania określonych zadań, proponowany układ poziomów jest całkowicie nieodpowiedni, tu bowiem wiodącym organem staje się wojewoda ${ }^{24}$, zatem organ usytuowany na poziomie województwa (regionu).

System zarządzania kryzysowego w Polsce wyznacza (przez wiele aktów normatywnych) zadania dla organów administracji rządowej i samorządowej. Określone zadania spoczywają na organach centralnych i terenowych. Wyznacznikiem jest ustawa o zarządzaniu kryzysowym, która „buduje” system polskiego zarządzania kryzysowego.

Ustawa powołuje „centra” i „zespoły” zarządzania kryzysowego. Na poziomie centralnym w oparciu o art. 10 powstało Rządowe Centrum Bezpieczeństwa. Na podstawie art. 11 zapewnia ono obsługę Rady Ministrów, Prezesa Rady Ministrów, „zespołu” i ministra właściwego do spraw wewnętrznych w sprawach zarządzania kryzysowego oraz pełni funkcję krajowego centrum zarządzania kryzysowego. Na poziomie centralnym organem zarządzania kryzysowego jest Rada Ministrów, Prezes Rady Ministrów oraz wskazywany wyżej minister. W oparciu o art. 8 rolę organu opiniodawczo-doradczego pełni powołany przy Radzie Ministrów Rządowy Zespół Zarządzania Kryzysowego. Jego przewodniczącym jest Prezes Rady Ministrów. W posiedzeniach Zespołu na prawach członka w zależności od potrzeb mogą brać udział ministrowie kierujący działami administracji rządowej i inne wy-

${ }^{24}$ Zgodnie z art. 2 ustawy z 23.01.2009 r. o wojewodzie i administracji rządowej w województwie (Dz.U. z 2017 r. poz. 2234 ze zm.) zadania administracji rządowej w województwie wykonują (poza wojewodą) między innymi organy administracji zespolonej oraz organy administracji niezespolonej, które konkretnie są wymienione w art. 56. 
mienione w art. 8 ust. 3 organy, np. Główny Lekarz Weterynarii, Komendant Główny Państwowej Straży Pożarnej, Komendant Główny Policji. Zatem na poziomie centralnym można mówić o centralizacji wykonywania zadań z dopuszczeniem do głosu w zakresie doradczym i opiniodawczym wielu szefów resortów i kierowników organów centralnych, co jest przejawem dekoncentracji działań.

Na poziomie województwa, powiatu i gminy sytuacja jest analogiczna w zakresie funkcjonowania odpowiednich „centrów”25 i „zespołów”26. Ważne jest jedynie podkreślenie, iż w regionie organem zarządzania kryzysowego nie jest organ samorządowy, lecz - zgodnie z art. 14 badanej ustawy - przedstawiciel rządu w terenie koordynujący odpowiedni system wojewódzkich służb, inspekcji i straży, którym jest wojewoda. Zarząd województwa jedynie uczestniczy w realizacji zadań z zakresu zarządzania kryzysowego, które odnoszą się do planowania cywilnego ${ }^{27}$. Zatem na tym etapie nie można jeszcze mówić o pełnej decentralizacji w zarządzaniu kryzysowym.

Natomiast w gminie i powiecie organami zarządzania kryzysowego są wykonawcze organy samorządowe. W gminie odpowiednio wójtowie, burmistrzowie i prezydenci miast, co potwierdza art. 19. Z kolei w powiecie - starostowie. Choć w zakresie ustrojowym samorządu są oni przewodniczącymi zarządu powiatu, to w przypadku koordynowania powiatowych służb, inspekcji i straży są organami zarządzania kryzysowego, o czym dodatkowo stanowi art. 17 ustawy o zarządzaniu kryzysowym.

Zadania, które mają być wykonywane przez „zespoły” i „centra”, wskazuje ustawa o zarządzaniu kryzysowym. Zasadniczo są one określone

${ }^{25}$ Wojewódzkie centra zarządzania kryzysowego powstają na mocy art. 16, powiatowe centra zarządzania kryzysowego powstają w oparciu o art. 18, natomiast gminne (miejskie) centra zarządzania kryzysowego tworzy się na mocy art. 20 (tworzone fakultatywnie) ustawy o zarządzaniu kryzysowym.

${ }^{26}$ Wojewódzki zespół zarządzania kryzysowego - art. 14 ust. 7, powiatowy zespół zarządzania kryzysowego - art. 17 ust. 4, gminny zespół zarządzania kryzysowego art. 19 ust. 4 ustawy o zarządzaniu kryzysowym.

${ }^{27}$ Por. art. 15 ustawy o zarządzaniu kryzysowym, zadania z zakresu planowania cywilnego znajdują się w art. 4 omawianej ustawy. 
w sposób bardzo ogólny. Jako przykład niech posłuży art. 9, w którym określono zadania Rządowego Zespół Zarządzania Kryzysowego w postaci „przygotowywania propozycji użycia sił i środków niezbędnych do opanowania sytuacji kryzysowych" oraz kilka zakresów o charakterze doradczym. Wykonywanie konkretnych zadań zależy od norm wpisanych do pragmatyk zawodowych służb, inspekcji i straży oraz od roli danego organu w systemie zarządzania kryzysowego, np. wynikającej $\mathrm{z}$ ustaw ustrojowych oraz wyznaczonej przez dokumenty planowe.

Reasumując, można uznać, iż decentralizacja w zarządzaniu kryzysowym jest niepełna i odnosi się do powiatu i gminy, a w odniesieniu do województwa występuje w ograniczonej postaci. Można nawet stwierdzić, że wykonywanie zadań od pewnego momentu przybiera postać działań scentralizowanych. W kontekście resortowości wykonywania określonych kategorii zadań ważna jest ich dekoncentracja. Odnosi się ona do wszystkich poziomów zarządzania kryzysowego. Z kolei możliwość wykorzystania Sił Zbrojnych Rzeczypospolitej Polskiej do wykonywania zadań w zakresie zarządzania kryzysowego ma postać scentralizowaną, ponieważ jest zadaniem Rządowego Centrum Bezpieczeństwa ${ }^{28}$.

\section{Podejmowanie konkretnych działań różnych podmiotów po nawałnicy w Borach Tucholskich}

Na wstępie tego fragmentu badań trzeba podkreślić, że używanie nazwy „Bory Tucholskie” należy rozumieć nie tylko jako ścisły obszar „formy ochrony przyrody” w postaci Parku Narodowego „Bory Tucholskie” z siedzibą w Charzykowach ${ }^{29}$, ale jako teren, przez który przeszła nawałnica, zarówno na jego obszarze, jak i w szerokiej jego okolicy, czyli częściowo w województwie pomorskim i w części województwa kujawsko-pomorskiego. Aspekt praktyczny dotyczy obserwacji, zwłaszcza terenu powiatu tucholskiego, częściowo chojnickiego i sę-

${ }^{28}$ Zob. art. 10 i 11 ustawy o zarządzaniu kryzysowym.

29 Zob. załącznik do ustawy z 16.04.2004 r. o ochronie przyrody (Dz.U. z 2018 r. poz. 1614 ze zm.) oraz art. 6 tego aktu. 
poleńskiego. Należy też dodać, że uproszczenie określenia do używanej postaci „Bory Tucholskie” służy poprawieniu czytelności rozważań.

Zgodnie $\mathrm{z}$ analizą wskazaną $\mathrm{w}$ wojewódzkim planie zarządzania kryzysowego województwa kujawsko-pomorskiego ${ }^{30}$ na obszarze województwa „przeważają wiatry z kierunków: zachodniego i południowo-zachodniego (ponad $40 \%$ częstości). Wichury i inne wiatry mogą spowodować lokalne utrudnienia w przejezdności dróg oraz uszkodzenia napowietrznych linii energetycznych i telefonicznych. Miejscowe zagrożenia mogą stanowić linie energetyczne wysokich napięć $110 \mathrm{KV}$ i $220 \mathrm{KV}$ ”. W planie pomorskim wskazano, iż „nawalny deszcz" może pojawiać się na obszarze całego województwa, $\mathrm{a}$ „wichury i wiatry są trudne do przewidzenia" ${ }^{\text {"1 }}$.

Apogeum wskazywanego wcześniej „bow echa” były silne wiatry, burze i trąby powietrzne. Na terenie Borów Tucholskich najczarniejszy scenariusz rozpoczął się późnym wieczorem 11 sierpnia i trwał niemal do rana dnia następnego. W wyniku nawałnicy zginęło sześć osób (w tym dwie harcerki z Łodzi). Odnotowano niespotykane dotąd zniszczenia mienia i lasów.

Zgodnie ze wskazanymi przez M. Stahl „cechami administracji” należy podkreślić, iż podejmowanie działań po nawałnicy powinno być ich odzwierciedleniem, zwłaszcza że chodzi tu o „działanie w interesie publicznym (w «imię dobra wspólnego», «interesu społecznego») $)^{32}$.

Po nawałnicy wszystkie podjęte działania, bez względu na rodzaj podmiotów, które w nich uczestniczyły, można podzielić na dwa etapy:

1) akcja ratunkowa;

2) akcja pomocowa.

${ }^{30}$ Zob. http://www.bip.bydgoszcz.uw.gov.pl/files/dokumenty/plan_zk_kujawsko_ pomorskie_czesc_i.pdf (dostęp: 2.11.2018 r.).

31 Zob. http://www.gdansk.uw.gov.pl/attachments/article/1545/Plan\%20G\%C5\% 82\% C3\%B3 wny\%20z\%20 Planu\%20Zarz\%C4\% 85 dzania\%20Kryzysowego \% 20Wojew\%C3\%B3dztwa\%20Pomorskiego.pdf (dostęp: 2.11.2018 r.), s. 15-16.

${ }^{32}$ M. Stahl, Cechy administracji [w:] Prawo administracyjne: pojęcia, instytucje, $z a-$ sady $w$ teorii i orzecznictwie, red. M. Stahl, Warszawa 2009, s. 17. 
Fotografia nr 1. Skutki zniszczenia lasu po nawałnicy w okolicy Woziwody.

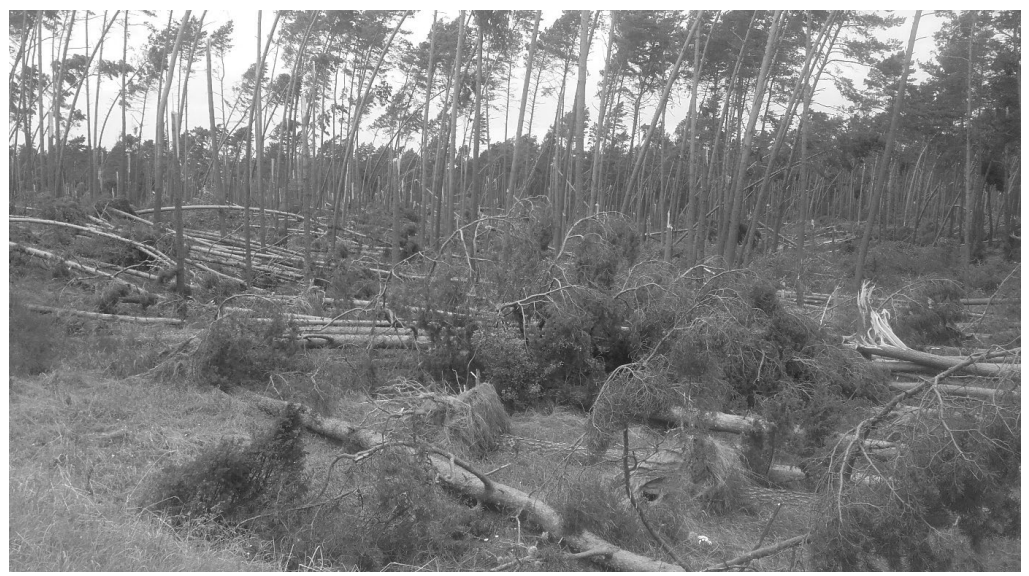

Źródło: fotografia własna wykonana 16.08.2017 r.

Fotografia nr 2. Skutki zniszczenia lasu przy drodze wojewódzkiej nr 237 z Czerska do Tucholi.

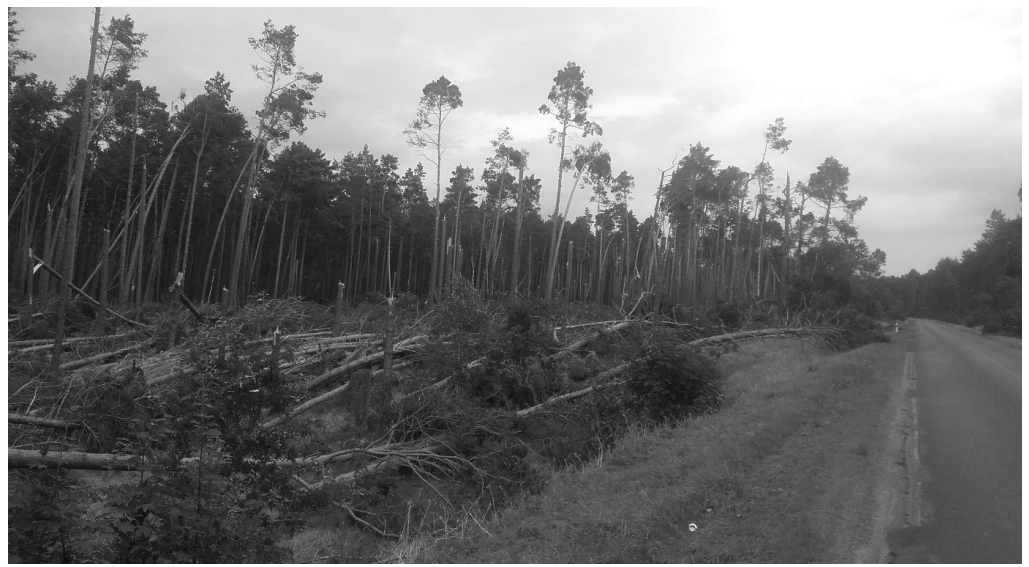

Źródło: fotografia własna wykonana 16.08.2017 r.

W praktyce wiodącą rolę $\mathrm{w}$ akcji ratunkowej na omawianym terenie dotkniętym kataklizmem odegrały jednostki ratowniczo-gaśnicze Państwowej Straży Pożarnej oraz ochotnicze straże pożarne. Do pierwszego etapu akcji włączone były, co oczywiste, służby medyczne i Policja. 
Nadzwyczajna liczba akcji ratunkowych podejmowanych przez strażaków wymagała szczególnej i nadzwyczajnej mobilizacji wszystkich dostępnych sił osobowych i środków technicznych.

Uszkodzenie części infrastruktury krytycznej oraz mienia na niespotykaną skalę zmusiło do wytężonego i ofiarnego działania wiele miejscowych służb, inspekcji i straży oraz samych mieszkańców. Przez wiele dni niektóre drogi były nieprzejezdne. Tysiące gospodarstw domowych było przez kilka dni bez wody i prądu. Nie działała telefonia komórkowa, a w niektórych rejonach - Internet. Zanim zorganizowano agregaty prądotwórcze, nie można było tankować paliwa, a w sklepach można było płacić za towar tylko gotówką. Po kilku dniach bez prądu w sklepach i domach produkty spożywcze stawały się przeterminowane. Tu istotną rolę odegrały lokalne media, informujące ${ }^{33}$ na bieżąco o decyzjach miejscowych organów i aktualnej sytuacji w zakresie wykonywania zadań przez różne podmioty ${ }^{34}$. Podjęto decyzję o zakazie wstępu do lasów na terenie poszczególnych nadleśnictw dotkniętych kataklizmem.

Nie można pominąć oddolnych działań mieszkańców podjętych zarówno w pierwszym, jak i drugim etapie akcji. Szczególne umiejętności organizacyjne na najniższych szczeblach władzy dzięki mediom obserwowała cała Polska. Mowa oczywiście o sołtysie niewielkiej wsi Rytel, który wraz z żoną już w pierwszych godzinach akcji ratunkowej zorganizował centrum kryzysowe w lokalnej świetlicy. Działania oddolne można było dostrzec od pierwszych minut po przejściu huraganu. Mieszkańcy pomagali sobie nawzajem w organizowaniu jedzenia, środków czystości oraz w drobnych pracach naprawczych.

${ }^{33}$ Co ciekawe, informacja dostępna na http://www.pomorska.pl/wiadomosci/naklo/a/ nawalnica-w-potulicach-rodziny-wiezniow-domagaja-sie-szybkich-dzialan,12394271/ (dostęp: 2.11.2018 r.) 17.08.2017 r., czyli 5 dni po nawałnicy jedną z lokalnych gazet poprosiły o interwencję rodziny osadzonych w jednym z zakładów karnych w województwie kujawsko-pomorskim. Ze względu na uszkodzenie infrastruktury telekomunikacyjnej nie mieli oni kontaktu z bliskimi, co, jak wskazywali, powoduje u nich znaczącą traumę.

${ }^{34}$ Na przykład dyrektor Wojewódzkiej Stacji Sanitarno-Epidemiologicznej w Bydgoszczy za pośrednictwem telewizji informował o zagrożeniu, jakim są przeterminowane produktu spożywcze. 
Jednym $\mathrm{z}$ istotnych zakresów interwencji ze strony władz centralnych okazało się uruchomienie środków pomocowych (np. 6 tys. zł z budżetu państwa dla każdego poszkodowanego gospodarstwa domowego, pomoc dla rolników) oraz medialna zapowiedź Prezes Rady Ministrów ograniczenia działalności monopolistycznej w celu przeciwdziałania zmowom cenowym na materiały budowlane.

Lokalna pomoc społeczna zajęła się rozpatrywaniem indywidualnych wniosków na środki mające służyć pokryciu kosztów naprawy konkretnych szkód. Lokalne władze zorganizowały stosowne komisje do spraw szacowania szkód. Po pięciu tygodniach od tragedii na kontach poszkodowanych nie pojawiły się jeszcze pieniądze (poza wskazywanymi ze środków centralnych - 6 tys. zł).

Ocena działalności władzy publicznej przez mieszkańców zasadniczo zależała od szybkości reakcji włodarzy poszczególnych jednostek samorządu terytorialnego. Co do funkcjonowania Powiatowego Centrum Zarządzania Kryzysowego w powiecie tucholskim jako komentarz niech posłuży strona BIP tego podmiotu, w której informacje w zakresie wykonywania przez centrum zadań ostatni raz aktualizowane były $16.12 .2013 \mathrm{r}^{35}$

Sytuacja po nawałnicy negatywnie wpłynęła na wizerunek miast, wsi i całego obszaru Borów Tucholskich. Stałym elementem tożsamości tego regionu są, co oczywiste, lasy i cała przyroda. W stały wygląd miasteczek i wsi wpisały się uwarunkowania historyczne i środowiskowe. Doszło do zachwiania budowanego przez wiele lat wizerunku regionu jako przyjaznego turystom mogącym korzystać z dobrodziejstw przyrodniczych. „Atrakcyjność środowiska naturalnego” wymieniana jest przez A. Stawicką-Traczyk w grupie czynników decydujących o atrakcyjności miasta ${ }^{36}$. W badanym przypadku założenie to można odnieść nie tylko do miast, ale także do terenu po wichurze w całym regionie.

35 Zob. http://www.bippowiat.tuchola.pl/?app=reg\&bip_id=625\&r=Y2lkPTI0OA== (dostęp: 2.11.2018 r.). Największe zmiany stanu prawnego w zakresie zarządzania kryzysowego nastąpiły właśnie w 2013 r. i zaczęły obowiązywać od 2.10.2013 r. Jednak prezentowane na BIP informacje nie do końca uwzględniają dokonane zmiany.

${ }^{36}$ A. Stawicka-Traczyk, Determinanty wizerunku miasta, ST 2009/10, s. 11. 
Na przykładzie Tucholi można stwierdzić, iż wizerunek miasta znacząco ucierpiał. W pierwszym tygodniu po kataklizmie na ulicach leżały fragmenty blachy, papy, dachówki i elementy elewacji oraz reklamy. Ogólnym sprzątaniem wszechobecnego bałaganu w mieście zajęła się lokalna firma zajmująca się gospodarowaniem odpadami i firmy dbające o zieleń miejską. W miejscach, gdzie głównym zagrożeniem dla bezpieczeństwa lub komunikacji były powalone drzewa, znacząco zaangażowano siły i środki, którymi dysponuje Komenda Powiatowa Państwowej Straży Pożarnej w Tucholi oraz druhowie ochotnicy. Po miesiącu od nawałnicy w mieście i w okolicznych wsiach nadal uprzątane były negatywne jej skutki. Nawet do wiosny 2018 r. obraz całych miejscowości, gdzie zamiast dachów zastosowano prowizoryczne plandeki, wcale nie był rzadkością.

W odniesieniu do lasów szacunki są zatrważające. Przyjmuje się, iż samo uprzątnięcie wiatrołomów zajmie odpowiednim podmiotom do tego zaangażowanym nawet 2-3 lata. Należy pamiętać, iż problem dotyka nie tylko PGL „Lasy Państwowe”, ale także licznych lasów prywatnych $^{37}$.

W pierwszym etapie wykonywania zadań w zakresie zarządzania kryzysowego z terenu Borów Tucholskich „wołanie o pomoc” dobiegło z najniższego szczebla samorządności, czyli od sołtysa Rytla i burmistrza Chojnic, którzy obawiając się powodzi, w obliczu ogromu prac do wykonania na rzece Brdzie, poprosili w mediach o wsparcie wojska. Oficjalny wniosek w tej sprawie do właściwego ministra od wojewody pomorskiego był tylko następstwem „medialnej burzy” w tym względzie.

37 W „Lasach Państwowych” powalone albo uszkodzone zostały drzewostany w około 60 nadleśnictwach z regionalnych dyrekcji w Toruniu, Gdańsku, Poznaniu, Szczecinku, Łodzi i Wrocławiu. Dane z http://www.lasy.gov.pl/pl/informacje/aktualnosci/najwieksza-taka-kleska-w-historii-polskich-lasow (dostęp: 2.11.2018 r.), gdzie także wskazano, iż „najbardziej ucierpiały dyrekcje toruńska i gdańska [czyli w większości Bory Tucholskie i okolice], a zwłaszcza nadleśnictwa Lipusz (aż 2,3 $\mathrm{mln}^{3}$ powalonych drzew), Rytel $\left(2 \mathrm{mln} \mathrm{m}^{3}\right)$, Czersk $\left(0,9 \mathrm{mln} \mathrm{m}^{3}\right)$, Bytów $\left(0,65 \mathrm{mln} \mathrm{m}^{3}\right)$, Runowo $\left(0,66 \mathrm{mln} \mathrm{m}^{3}\right)^{\prime}$. 


\section{Wnioski końcowe}

Choć założenia doktrynalne w zakresie terminów „centralizacja” i „decentralizacja” w odniesieniu do organów administracji publicznej nie budzą wątpliwości, to w praktyce są one nagminnie mylone z pojęciami koncentracji i dekoncentracji zadańn ${ }^{38}$.

Badanie pojęcia nawałnicy pokazuje, iż nie jest to pojęcie prawne. Ustawodawca określił jedynie pojęcie katastrofy naturalnej i wśród zagrożeń wymienił „silny wiatr”, ale nie „nawałnicę”. Jednak pozostawił katalog otwarty, uznając, iż katastrofą naturalną może być „inny żywioł”. Przepisy prawne odnoszą się także do pojęcia huraganu, które określone jest w ustawie z 7.07.2005 r. o ubezpieczeniu upraw rolnych i zwierząt gospodarskich ${ }^{39}$.

W kontekście zagrożeń na gruncie nauki ekologii „nawałnica” traktowana jest najczęściej jako zagrożenie naturalne. W sytuacji kryzysowej z udziałem nawałnic wykonywanie zadań odbywa się na podstawie ustawy o zarządzaniu kryzysowym, która określa system zarządzania kryzysowego w Polsce. W jego strukturze widoczne są zarówno elementy decentralizacji, ze względu na rolę, jaką odgrywają w nim jednostki samorządowe (i działające w nich organy samorządowe), jak i dekoncentracji, zadaniowość ma bowiem charakter resortowy. Na każdym poziomie znajdują się wyspecjalizowane organy (podmioty) odpowiedzialne za przedmiotowy zakres zadań.

Jednak w pierwszych godzinach i dniach po nawałnicy w Borach Tucholskich reakcja poszczególnych ogniw systemu na sytuację kryzysową nie we wszystkich przypadkach była odpowiednia. Poza tym zawiódł system ostrzegawczy. Błędem było bagatelizowanie skutków

${ }^{38}$ Można mówić nawet o pewnej „pladze” niezrozumienia różnicy pojęciowej, która obserwowana jest w doniesieniach medialnych. Jako przykład niech posłuży przekaz telewizyjny (16.09.2017 r.), gdzie ogłoszono planowaną przez władze publiczną reformę w zakresie delegowania części pracowników Inspekcji Transportu Drogowego do Białegostoku, używając w doniesieniach naprzemiennie oraz w różnych, błędnych kontekstach, wszystkich czterech pojęć.

39 Dz.U. z 2017 r. poz. 2047 ze zm. 
nawałnicy przez wojewodę pomorskiego. Jak się okazało, w praktyce najbardziej skuteczne działania oddolne (mieszkańców i organów) i resortowe, za które odpowiedzialni byli kierownicy, dyrektorzy i komendanci służb, inspekcji i straży.

\section{Bibliografia:}

Bednarzewski K., Chmielnicki P., Kisiel W., Prawo samorzadu terytorialnego w Polsce, Warszawa 2006

Boryczka J., Stopa-Boryczka M., Kożuchowski K., Zmiany klimatu wywołane przez człowieka [w:] Katastrofy i zagrożenia we wspótczesnym świecie, red. W. Baturo, Warszawa 2008

Bukowski Z., Jędrzejewski T., Rączka P., Ustrój samorządu terytorialnego, Toruń 2003

Encyklopedia powszechna PWN, red. H. Bonecki, t. 1, Warszawa 1973

Gierszewski J., Bezpieczeństwo wewnętrzne, Warszawa 2013

Graniczny M., Mizerski W., Katastrofy przyrodnicze, Warszawa 2007

Łuczyszyn A., Bezpieczeństwo państwa a rozwój społeczno-gospodarczy. Aspekt regionalny i lokalny, Warszawa 2016

Maciejewski M., Skuteczność jako wartość prawa administracyjnego i administracji publicznej [w:] Aksjologia prawa administracyjnego, red. J. Zimmermann, Warszawa 2017

Prawo administracyjne, red. M. Wierzbowski, Warszawa 1999

Sługocki J., Prawo administracyjne, Kraków 2003

Stahl M., Cechy administracji [w:] Prawo administracyjne: pojęcia, instytucje, zasady w teorii i orzecznictwie, red. M. Stahl, Warszawa 2009

Stawicka-Traczyk A., Determinanty wizerunku miasta, ST 2009/10 